\title{
THE EFFECTS OF COOPERATION ON THE PROFIT ECONOMY
}

\author{
George W. StarR*
}

I

Corporate and business profits are significant sources of tax revenues of the Federal Government. Such taxes also constitute an important expense for business firms paying them. ${ }^{1}$ Complete or partial freedom from the payment of corporation income taxes has long been a substantial competitive advantage to cooperatives, as has been demonstrated by their phenomenal growth. ${ }^{2}$ As a group cooperatives have attempted to justify tax exemption on the theory that the cooperative method of doing business does not give rise to net income or net profit: since there is neither net income nor net profit there is no base on which to levy an income tax. ${ }^{3}$

- B.Sc. 1921, M.Sc. I924, Ohio State University. Professor of Business Research and Director of the Bureau of Business Research, Indiana University, since I927. Author, (with Mark C. Mills) Readincs in Taxation and Public Finance (I93I). Consultant for the National Tax Equality Association, Chicago.

${ }^{2}$ Theoretical calculations based on the distribution of corporate earnings in 1946 indicate a federal income tax liability for a net profit before taxes of $\$ 100,000$ to be approximately the following for each type of business organization:

Individual proprietorshp $\$ 63,954$

Partnership (two individuals) $\$ 50,958$

Corporation $\$ 43,890$

It is assumed that the recipients of corporate dividends paid $\$ 5,890$ of the total tax of $\$ 43,890$ credited to the corporation.

2 Homer E. Marsh, The Facts in the Matter 34 (I947). Mr. Marsh estimates the I946 volume of cooperative business to have been $\$ \mathrm{r} 2,960,185,000$.

At the Hearings before the House Ways and Means Committee, November 10-26, 1947, the following witnesses on behalf of the cooperatives made these observations.

Mr. Wilfrid E. Rumble, counsel for the National Cocperative Milk Producers Federation and National Federation of Grain Cooperatives:

The cooperatives answer that a cooperative association is bound by a preexisting contractual obligation to return to its patrons on a patronage basis the entire net proceeds of its operations, less the amount payable on capital stock and the amount set aside for reserves; that such payment in the case of marketing cooperatives represents the final payment on the price the patron is entitled to receive for his products, and in the case of purchasing cooperatives these payments represent a reduction in cost to the patron of the goods purchased by him through the associaton, and that at no time does any part of such net proceeds belong to the cooperative association except that earned on the business of patrons to whom there is no such obligation, which does belong to the cooperative and is subject to tax. Hearings before the House Ways and Means Committee on Proposed Revisions of the Internal Revenue Code, Pt. 4, 8oth Cong., Ist Sess. 2113 (1947).

Mr. Karl D. Loos, counsel for National Council of Farmer Cooperatives, National Association of Cooperatives, National Cooperative Milk Producers Federation and National Federation of Grain Cooperatives:

The receipts of a farmer cooperative are, in reality, income to its members, and it is the members who are therefore liable for the payment of income taxes. Many corporations, furthermore, pay no income tax because, like the cooperatives, they have no income. In the ro-year period ending with r944, an average of 226,000 corporations paid taxes. An average of 236,000 paid no taxes because 
If cooperatives are profitless businesses in an economic sense, it must follow that they are riskless businesses. What happens to the risks in cooperative ventures must therefore be explained. Perhaps we may throw some light on these questions if we examine the nature of profits in our economy.

Profit exists in our economy because of uncertainty, and uncertainty exists with respect to everything in the future. Were the future an open book to everyone, there could be no profit. All business would be transacted at cost. Although profit-taking is popularly associated with risk, in a strictly technical sense this association is unwarranted. All risks may be covered in one way or another, frequently through insurance, and consequently risks become a measurable cost of doing business. Uncertainty which cannot be covered in any way, since it is not measurable, results in a profit or loss to the businessman assuming it. Individual uncertainties may often be combined in sufficient numbers to become effective certainties through the laws of chance. Life insurance is an example of making a certainty out of multiple uncertainties.

The major uncertainty of business is change. If nothing changed, there could be no profit. What prices in certain fields will be tomorrow, next month, or next year; what conditions of supply and demand will be; what new processes or new machines will be available soon; what consumer acceptance of a product will be, are a few everyday examples of uncertainty in business. Profit arises from the fact that businessmen must contract for goods and services in advance at fixed rateswages, rent, materials, etc.-and realize upon their utilization through the sale of the finished product. The prices of the productive services being the costs of production, changes in conditions give rise to profits by upsetting anticipations and producing a spread between the cost and the selling price. Hence the imperfect knowledge of the future, because of change, gives rise to profits. If all had complete knowledge of the future, competition would be perfect, and no profit would arise.

they reported no net income. The corporations which paid no taxes at the same time paid total dividends averaging $\$ 280,000,000$ a year.

Cooperatives are under contractual obligation to return to their patrons cverything above cost. These amounts constitute additional proceeds from the sale of products or adjustments in the cost of farm supplies. Under no possible interpretation can these sums constitute income to the cooperative because it never has the power of disposition but is obligated to pass them on to its patrons.

Mr. Eugene L. Hensel, counsel for National Association of Cooperatives:

Great significance attaches to the fact that the Treasury Department and the Bureau have so consistently adhered to the recognition of patronage refunds as not being income of cooperative corporations, particularly when the obligation to make the refunds is established pursuant to a preexisting contract between the cooperative corporation and its patrons, executed prior to the transactions between the corporation and the patrons. Id. at $26 \times 8$.

Mr. Walter L. Bradley, chairman of the Committee on Accounting for Cooperatives of the American Institute of Accountants, and representative for the National Association of Cooperatives:

A proprietary enterprise charges its customers a certain price for an article or for a service. The difference between the price charged and the cost thereof is retained by the proprietor. It enriches him and is a profit. It does not belong any longer to the eustomer nor revert to him.

Where a cooperative carries our a similar transaction, the difference between the price charged and the cost does not belong to the Association, does not enrich the Association, it is at all times the property and profit of the patron, and, under proper cooperative procedure, it should go back to him. 1d. at 2670. 
In the everyday world in which we live, time begets change and since all business transactions involve time, the existence of profit must follow. The common practice of the payment of patronage dividends by cooperatives is a dynamic illustration of the existence of profits. If cooperatives had the divine gift of foretelling the future infallibly and accurately they could do business at cost, and if all businessmen had the same supernatural gift cooperatives would have to do business at cost. Things being as they are, and not as they might be, cooperatives along with all other forms of business organizations do business on a profit basis.

Cooperatives earn their profits in the same manner as does the ordinary corporation. The typical cooperative has an operating profit or loss at the end of its fiscal period which may be increased or diminished by other income or expense. In the conduct of its business the cooperative has bought at market prices, paid prevailing wages, and sold its product at standard prices. Its relations both with the public and with its employees have been no different from those of the ordinary corporation.

At the end of the fiscal period, when other income-usually patronage dividends from overhead cooperative organizations, affiliates, or subsidiaries-has been added to the operating profit, a patronage dividend is declared, provided that funds are available for distribution after the so-called "necessary reserves" have been taken out. With the exception of placing funds in "necessary reserves," this is much the same procedure followed by the ordinary corporation in distributing its profit among its stockholders.

A question naturally arises over the distribution of the profits: To whom do the profits belong? In theory this question is readily answered; in practice the answer is somewhat more difficult. In theory the profit belongs to those whose income depends upon the outcome of the venture-the gain, if any, which arises from the risk run because of the uncertainty of the future. In a single proprietorship, or in the usual partnership, for example, those who have invested their funds and who have directed the business have usually run the risks and are entitled to the profit, if any.

Under the corporate form of organization, cooperative or otherwise, the functions of management and of investment, or ownership, are usually separated. The manager, whose responsibility is the minimization of risk and the maximization of profit, is paid a fixed income, frequently unrelated to the amount of profit. Consequently the profit belongs to those who assume the risk, and who through skill or chance forecast the future more accurately than their competitors and reap a reward for the business in the form of a profit. Here again theory presents a much clearer picture of what happens in the operation of a corporation or cooperative than does actual practice. In theory, the profit belongs to the stockholders in the corporation or the cooperative, since it has been their skill or fortune in directing the affairs of the business which has resulted in the profit. The stockholders have chosen the directors, and the latter have employed the management. 
There is this difference between the distribution of a cooperative profit and the distribution of the profit of the ordinary corporation: ordinary corporation profits are distributed among those who have invested funds in the business, and as such are entitled to share in the profits of the corporation. The profits of the cooperative are distributed among those who have been the customers of the cooperative, on the basis of the volume of the business which they have furnished, and not on the basis of their investment in the business.

Consequently, some may have no investment in the cooperative, and thus are not economically entitled to any distribution of profits, since they have assumed no risk. In these cases the distribution of profits on the part of the cooperative is out-and-out profit sharing, taxable to the ordinary corporation.

Since cooperatives are expanding organizations, it is probable that a portion of every cash patronage dividend distributed by a cooperative represents payments to persons who have contributed no capital and have assumed no risk. Such patronage dividends are actually contributions out of profits for purposes taxable to the ordinary corporation.

Cooperative distributions represent the spread between cost prices and selling prices. They are distributed only after the accounts of the business are cast up, and the operating profit and other income are determined. Since cooperatives form regional, and in some cases national organizations engaged in many phases of production and distribution, and each cooperative is both a customer of and an investor in one or more other cooperatives, it follows that profits flow from one cooperative to another, and may come to rest as patronage dividends many cooperative stages away from the originating company. ${ }^{4}$

Thus the patronage dividend of the cooperative standing between the individual patron and the national network of manufacturing and distributing cooperatives may be a composite of the commingling of the almost endless profit transactions of the network. How these profits are measured is not material; they may be in relation to dollars of sales, physical units of output, percentages of net worth, or any other convenient measure. Net profit does not necessarily need to be related to net worth or stockholders' investment.

The Cooperative Grange League Federation Exchange is typical of the growth of holding companies among cooperatives. According to its annual report for $1945-46$, the Cooperative G.L.F. Exchange is the sole owner of the Cooperative G.L.F. Holding Corporation. Under the G.L.F. Holding Corporation are Cooperative G.L.F. Credit Corporation; Cooperative G.L.F. Farm Products, Inc., which in turn owns thirteen sales terminals and auctions, three bean plants, two milling services, three canning plants and three cold-storage plants; Cooperative G.L.F. Soil Building Service, Inc., which owns ten fertilizer plants; Cooperative G.L.F. Farm Supplies, Inc., which owns seven warehouscs, one basket factory, and two petroleum terminals; and Cooperative G.L.F. Mills, Inc., which owns three feed mills and five seed plants.

In addition, the Holding Corporation owns 47 bulk petroleum plants operating under the name G.L.F. Petroleum Cooperative, Inc., 18 marketing stores operating under the name G.L.F. Cooperative, Inc., and 215 retail service stores operating under the name Cooperative G.L.F. Service, Ine.

The G.L.F. Cooperative is also affiliated with the Cooperative P \& C Family Foods, Inc., United Cooperatives, Cooperative G.L.F. Farm Service, Inc., Inland G.L.F. Trading Co-op, Jersey Trucking Service, and Fertilizer Manufacturing Cooperative, Inc.

The Ohio Farm Bureau Federation, Inc., and the Indiana Farm Burcau Cooperative Association are other large holding corporations in the cooperative field. 
Investors in a cooperative, whether they have come by their investment through the receipt of patronage dividends in the form of stock certificates or whether they have purchased their stock, are investing in a share not of any physical goods, but of pecuniary rights. Investors in a cooperative, like investors in private corporations, buy a claim on earning power. If any recipient of a stock certificate were to go to the plant of the cooperative and ask to see his property, no one could show it to him. He would not own machines, buildings, or raw or finished materials. He owns a share in earning capacity, and he has acquired the right to profits, either through purchase or patronage dividends; he cares not from where they come.

Few stockholders take an active interest in the management of the businesses in which they invest their funds, and apparently in the management of cooperatives this characteristic lack of interest is even more prevalent than among the ordinary corporations. Among ordinary corporations the voice of the stockholder in the selection of the management is usually proportional to his control over voting stock; consequently, the larger his holdings, the greater his interest in the selection of the management. In the typical cooperative each shareholder has but a single vote, and a vast majority of the stockholders exercise no control in the selection of the management. In fact, in the typical subsidiary cooperative only a small percentage of the stockholders know how the directors of the central organization are chosen.

The control of the cooperative is no different in principle from that of any ordinary corporation, despite the fact that each stockholder is limited to a single vote irrespective of the number of shares he may own. One objective of the corporate form of cooperative organization is to concentrate executive control and direction and at the same time to scatter ownership. The limitation of each stockholder to a single vote may in some cases permit even a higher concentration of control than is normal in an ordinary corporation. The more the ownership of a cooperative is scattered, the easier it is for a limited number of persons to control its operations.

The payment of patronage dividends in preferred stocks, instead of cash or common stock certificates-a common practice where a cooperative is expanding rapidly-has the effect of affording a maximum spread of ownership without impairing the control of a small group of common stockholders.

\section{II}

The exemption of cooperatives from federal income taxes has not resulted in lower prices to the patron. There are several reasons why this has not happened, and why it may not be expected to happen under tax exemption. In the first place, the cooperative is in business for profit, and has no desire to operate at a loss, or even at cost. Cooperative leaders have repeatedly emphasized the necessity of selling at the competitive price so that they may be regarded as fair competitors by their private business neighbors. Repeated checks throughout the country 
have revealed that cooperative prices are the prevailing prices in the community. A check last spring by the newspaper $P M$ in New York revealed that prices in consumer cooperative food stores in the New York metropolitan area were midway between the highest and lowest prices for the same or comparable items charged by the better-known groceries. ${ }^{5}$ Marketing of its products at cost would direct the attention of private business competitors and of the public to the economic effects of the cooperative's tax-exemption subsidy. Consequently, the less disturbing method of operation from the standpoint of public relations in its community is for the cooperative to sell its products at prevailing prices and to distribute the profit of the operation through cash dividends, or use it in the business for further expansion. In this connection it must not be overlooked that the prevailing prices charged by the cooperative include an added charge covering the corporate income tax which accrues as tax exempt income to the cooperative. Many cooperative leaders have pointed out that any taxation of the cooperative as a business would be met by price cutting on its part. ${ }^{8}$ The implication of this threat is that the cooperative by some economic sleight of hand would offset its tax liability by price reductions. In doing business at actual cost at all stages in the process of production and distribution, cooperatives would have the same costs as the ordinary corporation, if the two types or organizations were equally efficient, and the difference between the prices charged by the cooperative and the ordinary corporation would be the net profit per unit of sale earned by the ordinary corporation.

Net profit in business is a comparably small item per unit of sale, as has been demonstrated by some of the reports of the Federal Trade Commission. ${ }^{7}$ Over a long period of time doing business at cost is almost a practical impossibility. It is not possible to marshal the quantities of free capital necessary to conduct at cost a business the size of the present-day cooperatives. A business conducted on a strictly cost basis would ultimately become so inefficient that it would be unable to do business even at cost; it would do business only at a loss. The one factor which has been responsible for the high standard of living in the free-enterprise countries, as compared with the standards in other countries, is that men work more cheaply and also harder for an uncertain return-and profit is the most uncertain of all returns-than they do for a fixed income or compensation. Remove the profit incentive from the cooperative structure and it will ultimately collapse under its own weight.

For a short time, until they had used up their accumulations of "necessary reserves," cooperatives might operate at or near cost. In the beginning they would probably operate at a loss, but once the reserves were dissipated, cooperatives would either return to the profit system or slowly disappear from the economic scene.

We must recognize, however, that as long as the present tax inequality exists

${ }^{8} \mathrm{PM}$, Jan 20, 1946, p. 16, col. 5.

- Cowden, Co-ops, Business Week, Jan. 22, I944, p. 84.

'Federat Trade Comanssion, Report on Distribution Methods and Costs, Pt. 4, p. 15, March 2, 1944 . 
between private business and the cooperatives the threat on the part of the cooperatives to sell at cost could be very real and very disastrous to the tax-paying businessman. As long as the cooperatives retain the tax-exemption subsidy, selling at cost on the part of the cooperative will not really be selling at cost. Cooperatives would not sell at their cost, but at the cost of the private distributor.

Profitwise, the price advantage of tax exemption is substantial, since often it may represent savings pyramiding at all stages between the producer and the consumer, if the product is produced and distributed cooperatively. Figures on average net profits per dollar of sales at the manufacturing, wholesaling, and retailing levels for all commodities are not available, but the cost-of-distribution inquiry made by the Federal Trade Commission in I943 and I944 indicates the average net profit at the manufacturing, wholesaling, and retailing levels for many specific commodities. $^{8}$

The figures from this inquiry have been quoted by cooperatives to indicate the savings which can be made by the cooperative method of production and distribution. Using the Federal Trade Commission figures on profits, it becomes apparent that the savings which accrue per dollar of sale through tax exemption at the manufacturing, wholesaling, and retailing levels usually are about twice as large as the net profit of the fully taxed retailer on the same merchandise.

Thus, through tax exemption at the three levels indicated, a cooperative distributing goods at the retail level could, by passing part of its tax subsidy along to the customer, price its merchandise so low that a competing tax-paying retailer could make no net profit selling the same merchandise; yet at the reduced price the cooperative would still make as large a net profit as the competing tax-paying retailer could make if he sold the merchandise at the regular price.

The value of the tax-exemption subsidy has risen as the cooperatives have directed more and more of their investment into manufacturing rather than distributing facilities. Under stable business conditions and tax rates, prices of taxpaying companies are prone to stabilize around a level which will earn a going rate of return on the investment after the payment of taxes. Under normal conditions this is bound to take place in an economy of competitive tax-paying private businesses. Corporate tax liability on a given volume of profits becomes an increasingly larger percentage of the cost or selling price as the rate of capital turnover decreases.

Thus in the retail fields, where the turnover of capital may be quite rapid, the tax-exemption subsidy per dollar of sales may be quite low-in some cases as low as one per cent of the selling price. On the other hand, in the manufacturing business, where the turnover is usually quite slow, the subsidy advantage may be as high as 15 to 20 per cent of sales. This greater tax advantage at the manufacturing level, along with the advantage gained from the complete integration of operations, no doubt has been responsible for the rapid expansion of the cooperatives in the manufacturing and mineral production fields.

id. at $x 9$. 
In the long run, the distribution of profits on the basis of patronage rather than stock ownership, as practiced by the cooperatives, is little different from the normal distribution of profits by the ordinary corporation. The stockholder in the ordinary corporation purchases stock with funds which he possesses or at least controls; among cooperatives, the management withholds the profits of the patron and uses them in the cooperative as a matter of course. The distribution of patronage dividends in the form of stock certificates over a relatively short time makes the larger patrons also the larger stockholders. Thus among cooperatives, as in ordinary corporations, the larger stockholders receive the larger aggregate of dividends.

The necessity of paying dividends on stock is much less real in the case of a cooperative than in the case of an ordinary corporation. Many, if not a majority, of the patrons of a cooperative have never had physical possession of the funds represented by the stock certificates which they own, and are prone to regard their patronage dividends as a return on the stock. Over the short term at least, patrons will be satisfied with stock certificates in lieu of cash payments for either stock dividends or patronage dividends. Under these conditions the full amount of the profits may be retained for further expansion.

We should recognize that the retention of the profits by the cooperatives through the distribution of stock dividends not only may be the retention as profits of taxes payable by the ordinary corporation under corporate income-tax laws, but also may result in the retention of earnings for which the ordinary corporation, especially the small, closely held corporation, would be penalized up to 27 per cent under Section ro2 of the Internal Revenue Code. The ability to retain profits payable by the ordinary corporations under normal corporate income-tax rates or under Section 102 is the reason why cooperatives are able to expand much more rapidly in their early stages than can the ordinary business.

Reserves and allocations have been used by cooperatives to gain many peculiar ends, which may not be pursued by the ordinary corporation without tax penalties. As a matter of fact, the ordinary small, closely held corporation may often experience difficulty in escaping the penalties of Section to2 in the setting up of really necessary reserves. The Treasury has also taken the position for income-tax purposes that the ordinary corporation may not donate more than 5 per cent of its profits, no matter how worthy the cause, without paying taxes on the donation, ${ }^{0}$ but allows many cooperatives to dispose of roo per cent of their earnings for any use that may gratify the management, without the payment of any taxes.

It has not been accidental that cooperatives have chosen the corporate form of organization, which has some very valuable advantages. In the first place, both the ordinary corporation and the cooperative form of organization protect their members from any personal liability which would arise if they were organized: as partnerships or if they merely acted as agents for their members. The members of a cooperative have no liability as such; only the property of the cooperative is liable. Second, both ordinary corporations and cooperatives have the status of an

${ }^{9}$ INT. Rev. CODE §23(q), U. S. Treas. Reg. III, §29.23(a)-I3 (1943). 
individual for purposes of property ownership, execution of contracts, and the general conduct of business. Finally, their status, and the ability to conduct business, is unaffected by the death, bankruptcy, withdrawal, or personal conduct of individual members.

It should also be recognized that the corporate form of organization is almost a must for holding-company control, a practice which is becoming almost universal among integrated cooperatives.

These advantages explain why both ordinary businesses and cooperatives choose the corporate form of organization for the purposes of marshaling quantities of capital and labor in the production and distribution of goods. No one can say that the advantages just enumerated are not substantial, and that business organizations should not pay taxes for the privilege of having the advantages. The widespread use of the corporate form of organization, despite the heavy taxes levied on the profits of ordinary corporations, is in itself evidence of its value.

That cooperatives can pay taxes and grow has been demonstrated by the experience of those which have done so, notably the Merrimac Farmers Exchange of Concord, New Hampshire. ${ }^{10}$ Because of some of the provisions of its charter the Merrimac Farmers Exchange is not tax exempt. During the past three years the cooperative has earned a total net income of $\$ 480,039$ and has paid federal income and excess profits taxes of $\$ 288,588$. The Exchange has always paid a cash dividend of 6 per cent to its stockholders, but to date it has paid no patronage dividends.

Since it began operations in I920, the Exchange has grown to an organization with eighteen branch stores serving 5,000 farmers, or one out of every four farmers in New Hampshire. It retails feed, grain, farm machinery, tools, etc. In Ig45 the Exchange had total sales of $\$ 12,282,822$, an increase of 300 per cent over the last pre-war year. From the experience of the Merrimac Farmers Exchange it may be seen that cooperatives can grow, and grow steadily, and yet carry their share of the cost of government.11

Mr. J. A. McConnell, manager of the Grange League Federation, in his annual report of October $3 \mathrm{r}$, I946, made this observation:

Perhaps some of our GLF committeemen may fear that if we should go on a tax paying basis, it would be impossible to build up adequate reserves for the protection of our GLF stores against lean years. Twenty-five years ago this might have been probably true. Today, I am of the opinion, based on a lot of experience, that as the rules and regulations are tightened in respect to exempt cooperatives as they are and will continue to be-that building up the necessary reserves in our GLF stores, to the point prudent business methods require, will be more difficult on an income tax exempt basis than it would be on an income tax paying basis. ${ }^{12}$

Apparently there are those within the cooperatives themselves who see the inequity of the present income-tax exemption basis.

\footnotetext{
${ }^{10}$ Merrimac Farmers Exchange, 24th-26th Anndal Financial Statement, 1944-46.

11 Ibid.

12 Report to Grange League Federation Committeemen, 946.
} 
If cooperatives have a place in the economic organization of our society, they should maintain their position through efficiency and not through a tax subsidy. If cooperatives must have tax subsidies to exist, then they must be a less efficient method of production and distribution than their counterpart, the ordinary corporation. Businesses that need a tax advantage of nearly one-third have no place in a free-enterprise economy. Nor should we aid any business or industry by granting a tax-exemption subsidy to only that part which happens to conduct its affairs according to a certain plan.

It is obvious that the present mixed economy, of tax-exempt and tax-paying competitive businesses, like a nation half free and half slave, cannot continue indefinitely. Unless this situation is corrected by the Congress the tax-exempt proportion will become progressively greater, and its beneficiaries will become an evergrowing political and economic force in our country. The greater the area of full or partial tax exemption becomes, the higher taxes will be on the tax-paying sector, and the greater will be the competitive advantage of tax exemption. Ultimately, even prohibitive taxes on the non-exempt businesses will yield insufficient revenues for the support of the government. The progressive narrowing of the tax base and the raising of taxes because of the expansion of the tax-exempt cooperatives can in the end have only one result-the disappearance of private business as we know it today.

The exemption of cash dividends from taxation, for both cooperatives and ordinary corporations, will not equalize the tax liability, nor is it sound from the standpoint of economics. Profits are derived from the operations of the business, whether paid out or retained in the business. In either event they should be taxable to the cooperative or the corporation. The elimination of cash dividends from taxation would continue to give the cooperative a tax advantage over the private corporation, since the exempt farmers' cooperative may retain its entire net profit in the guise of setting up reserves for "necessary purposes." The consumer or nonexempt farmers' cooperative might accomplish the same end through allocation of profits on its books.

From an economic standpoint, the payment of patronage dividends would still be a distribution of profits, either as à distribution of the profit to stockholders who might also be customers, or as a profit-sharing device to those who did not happen to be stockholders. As long as we continued to recognize profits as an indication of ability to pay taxes, and based our tax collections on profits, one part of the corporation's profit would go untaxed while the other would be taxed. The existence of profit would no longer be the basis of tax liability; its distribution would become the sole criterion. Undoubtedly other methods of tax avoidance would arise under a system which recognized only the disposition of profits, and not their existence, as the measure of ability to pay.

Under the current statutes and regulations covering the handling of reserves by exempt cooperatives, the elimination of cash dividends from taxation by both 
cooperatives and ordinary corporations would result in extreme discrimination against ordinary corporations, since the exempt cooperatives would make the decision on the amount of taxes they would wish to pay. The non-exempt cooperative, likewise, could retain the bulk of its earnings if it so desired, through the process of allocating its reserves to the various patrons. By these methods all coopera. tives could continue to escape most, if not all, taxation, if they so desired.

The payment of patronage dividends by ordinary corporations is not a solution to the tax inequality which now exists between ordinary corporations and the cooperatives. This system would ignore the responsibility of present corporate managements to their equity stockholders, who are not identical with the customers of the corporation.

The cost of government can be met through taxation by means of either of two broad fiscal policies: high taxes may be applied to a relatively narrow base, or relatively low taxes may be applied to a broad base. There are many reasons why the latter is much the preferred fiscal policy. Cooperatives as a group are a big business. Exempting cooperatives not only permits some hundreds of millions of dollars in current income to go untaxed, but also permits this amount to be used to expand investment in tax-exempt businesses. In a stable business situation, the reinvestment of these escaped taxes in tax-exempt cooperatives could curtail the tax-paying business economy by an equal amount each year.

What is perhaps more significant than the exact size of the curtailment of the tax base each year by the reinvestment of cooperative profits is the fact that this curtailment is being financed by the Federal Government through its loss in income-tax revenues. Since the chief source of receipts of the Federal Government is the collection of taxes levied on private businesses, it follows that the expansion of tax-exempt cooperatives is being financed by the tax-paying private businesses. The inclusion of the cooperatives in the tax levies on the same basis as the ordinary corporation not only will equalize the opportunity of earning a profit between the two large segments of our economy, but also in broadening the base will decrease the rates needed to yield a certain total return.

\section{III}

One of the objectives of cooperation, according to many leaders in the field, has been "production for use" and the reduction of profits through competition-that is, cooperative competition. Although the cooperatives claim on one hand to do business at cost, thereby, according to the claim, eliminating all profit, they set forth, on the other hand, as one of their objectives the reduction of excessive profits on the part of private business through cooperative competition. If the time should come when most of the business in all lines is handled by the subsidized cooperatives, then the profit of private business would be reduced by cooperative competition; in fact, it would disappear, and so ultimately would private tax-paying business. It is clear from a study of cooperative literature that any profits on the 
part of a private tax-paying business are excessive from the point of view of the cooperative leaders. ${ }^{13}$

The cooperative ciaim of reducing profits through increased competition is only a half truth. Subsidized competition, if of sufficient volume, will reduce profits in any field, as long as the competition exists. Sooner or later, however, this kind of competition drives out the competitors, and competition disappears. This has already happened in some areas where cooperatives have practical monopolies. ${ }^{14}$ Monopoly pricing by cooperatives is no more palatable and no less effective than it is in private business.

If the history of the cooperative movement in other countries may be relied upon, we have every reason to believe that the end result of a cooperative economy must be some kind of statism, which will ultimately gravitate into a totalitarian regime. All the totalitarian regimes of modern times have had their origin in some kind of production-for-use (rather than for profit) economy, in which cooperation of some form was an important cornerstone. The theory of production for use rather than for profit, the substitution of probable security for the ownership of property, eventually lead to more and more interference by the state, and finally the complete supremacy of the state over the individual. Thus regimes begin as socialist economies and end as completely totalitarian states. In this progression of the expansion of state functions and powers, the first and easiest step is that from cooperation to socialism, since both have the same objective-the elimination of profits and the production for use rather than for profit.

If one reads much of the literature of the cooperative movement and of the principles of socialism he is struck by the parallelism of ideas. In his book, Cooperative Democracy, James Peter Warbasse, president emeritus of the Cooperative League of the United States of America, says:

The ultimate destiny of the consumers' cooperative movement is to obtain or to produce in factory, shop, mine, sea, air, and land, all that consumers require.

As cooperation grows, the need and possibility of the existence of profit business and of the political state decline. ${ }^{15}$

In the Fifteenth Annual Report of the Consumers Cooperative Association, Howard A. Cowden, president, said:

The consumer cooperative movement in the United States is beginning to emerge as a national movement. Regional cooperative wholesales have joined hands on a national

${ }^{13}$ IVAN V. EMerianofF, Economic Theory of CoOperation 10-15 (1942).

14 According to Homer E. Marsh, the California Fruit Growers Exchange handled more than 85 per cent of all lemons marketed in the United States in 1946; the California Walnut Growers Association handles 80 per cent of California's merchantable walnuts and 73 per cent of all walnuts grown in the United States; the Calavo Growers of California control 76 per cent of the California avocado crop, approximately two-thirds of the nation's avocado crop being grown in California; the American Cranberry Exchange, a marketing agency for fresh fruit, and Cranberry Canners, Inc., processors, dispose of 70 per cent of the nation's cranberry crop. Homer E. Marsh, The FActs in the MATtrer $76-77$ (1947).

${ }^{28}$ James Peter Warbasse, Cooperattve Democracy 266 (1936). 
basis in petroleum, in the manufacture of power farming equipment, and in the production of milking machines for dairy farmers. There will be other examples of such teamwork in other fields shortly. Then to unite with cooperatives internationally in production and distribution will be a next and relatively easy step. ${ }^{16}$

In a circular letter to the cooperative membership sent out from South St. Paul, Minnesota, on April 30, r946, Charles D. Egley, then manager of the Farmers Union Livestock Commission Company, said:

The profit system concentrates wealth in the hands of the few, it exploits the masses; robs them of their purchasing power, as a result of which they cannot buy back what they produce.

To solve this problem it is, therefore, our opinion that we must get rid of the profit system and replace it with the cooperative system.

Mr. Egley's observations are not new. They can be traced back to the thinking of those early leaders of the cooperative movement in England, Sidney and Beatrice Webb, who in more recent years have been prominent in the British labor movement. ${ }^{17}$

These have been more or less random quotations from the literature of the cooperatives. They are quotations from responsible leaders in the field, and are representative of the thinking of those who direct the movement in this country.

The late Leonard Sydney Woolf, in his book, Socialism and Cooperation, points out:

... the socialist aims at building up society on a basis of cooperation between the units, whether individuals or classes, of society and at making, therefore, not competition or private profit, but communal interests or communal service the visible end of social activities in every day life. ${ }^{18}$

Our main purpose must be the transfer of the ownership of the instruments of industrial production and the control of industry from the.capitalist and capitalist company to the community of consumers, organized cooperatively, in such a way that the transfer is accompanied by a growth of socialist psychology of production and consumption. The impetus to this transfer must, of course, come from the anti-capitalist classes, in other words, from workers and the cooperators. The cooperator has two tasks before him ... he has to work for the utmost possible extension of cooperative industry, with the explicit intention of converting his movement into the instrument by which the community, organized as consumers, may control the whole of industry. ${ }^{18}$

Since Mr. Woolf was educated, and lived most of his life, in London, he had Great Britain in mind when he discussed the objectives of socialism. The rise of the present socialist Labor Party has given implementation to the objectives sought by him.

What is occurring in Great Britain has alsa taken place in a smaller way in our next-door neighbor, Saskatchewan, under the socialistic Cooperative Commonwealth Federation Party. The province of Saskatchewan has taken over some fourteen industries, ranging from furs to insurance. The latest to be acquired was an air

\footnotetext{
10 Consumers Cooperative Association, I5th Annual Report, I943.

${ }^{27}$ Stdney and Beatrice Webi, The Consumers' Cooperative Movement 8 (1930).

${ }^{18}$ LeONard Sydney WoOlf, Socialism AND CoOperation 23 (I92i).

10 Id. at Ir2.
} 
line. Since Saskatchewan has long been the stronghold of the cooperative movement in Canada, it naturally would be the first province to socialize its industries.

The transition from cooperation to socialism has thus far occurred only outside of the United States, and many would regard the possibility of such a transition in the United States as quite remote. No one knows the affiliation of any of the leaders of the cooperative movement in the United States, much less the political philosophies of the rank and file of its members. As a matter of fact, many of the leaders of the cooperative movement have been most outspoken against some of the political systems of Europe. Other leaders have repeatedly insisted that the cooperative movement is the strongest possible barrier against the introduction of socialism, communism, and other anti-capitalistic political philosophies.

A majority, if not all, of the cooperative leaders who have taken this position are doubtless sincere in their position on the matter-they actually see cooperation as a bulwark against socialism and other statist regimes. But we must not overlook the fact that this has been the position of many cooperative leaders in the past in countries that no longer have a capitalistic economy.

Those who have taken the position that a cooperative economy is the best guarantee against a statist regime overlook the fundamental fact that both the cooperative system and the various statist systems-socialism, communism, etc.-have as a common objective the elimination of the profit system. They also overlook the further fact that nothing unites political or economic groups, even if in many ways dissimilar, like a common enemy. In both the cooperative movement and in the various "-ism" regimes, the common enemy has been the profit system; given enough time and support they will unite to do away with profits.

In our present-day civilization one generation inherits from its predecessor material goods, knowledge and skill, and morale. If we are to progress as a nation these things must be passed on from one generation to the next. The present system of private capitalism and the private family, with the transfer of property and responsibility through inheritance, affords one way of moving the accumulations from one generation to another. Before we scrap private capitalism we should be sure what we want, and what it will provide. The elimination of the profit system would scrap private capitalism, and a tax-free cooperative system will ultimately eliminate the profit system. Standing on its own feet, cooperation can never displace private capitalism in the United States. It will continue to expand at the expense of private business only as long as it is subsidized through tax exemption, government grants, virtually interest-free loans, and outright gifts from the federal treasury. Private business is not opposed to cooperation as a method of doing business; it is opposed only to the inequality which now exists in the competition between the cooperatives and other types of business because of federal tax laws and Treasury regulations. If any business, cooperative or otherwise, takes advantage of the corporate form of organization, it should pay taxes for the privilege; and as long as one of the measures of tax liability is net profit, taxes should be levied on the existence of that profit and not on the method of its distribution. 